UDC 664.9.022

JEL Classification: L66

DOI: 10.15587/2706-5448.2021.229693

Article type «Reports on Research Projects»

\section{Iryna Vasenko, Tetiana Semko, Olga Ivanisheva}

\title{
FUNCTIONING ANALYSIS OF MEAT PROCESSING INDUSTRY IN MODERN CONDITIONS ON THE EXAMPLE OF UKRAINE
}

The object of research is meat processing enterprises on the example of Ukraine. One of the most problematic areas is the reduction in total beef and pork production. This negatively affects the development of the industry, which loses the opportunity to develop, create new jobs, enter the international market.

In the course of the study, general scientific and special methods were used. For example, the monographic method, methods of statistical grouping and correlation-regression analysis, as well as the graphical method were used to comprehensively study the current state of meat production. The grouping method was used to determine the influence of various factors on the level of efficiency in the production of different types of meat, and the comparison method was used to carry out a comparative analysis of the production of meat products in different time periods.

It is shown that in the general structure of agricultural production livestock products during 2015-2019 ranged from 24.1 to $20.9 \%$ of the total. The largest percentage in this structure was occupied by breeding farm animals. The smallest share in this production is occupied by beef and veal. And its production continues to fall. Negative dynamics was also observed in pork production. The production of sausages is relatively stable. The largest volumes of production were provided by chicken. The Ukrainian market of meat and meat products is closely connected with the development of raw materials for the industry. The total number of farm animals by farm category is declining, excluding poultry.

The wholesale turnover of meat and meat wholesalers has been growing every year. Raw material production and processing are closely interrelated. Today, it is extremely important to reconcile the interests of producers and processors so that the market is predictable, has a defined development strategy, focused on increasing domestic consumption and to realize the export potential of the meat industry.

Keywords: meat industry, meat processing enterprises, meat production, agricultural enterprises, households.

\section{How to cite}

Vlasenko, I., Semko, T., Ivanisheva, O. (2021). Functioning analysis of meat processing industry in modern conditions on the example of Ukraine. Technology Audit and Production Reserves, 2 (4 (58)), 12-15. doi: http://doi.org/10.15587/2706-5448.2021.229693

\section{Introduction}

The meat industry is a leading industry in the agricultural economy of many countries [1]. Meat and meat products of all kinds are traditional in the diet of many peoples [2]. However, analyzing the total production of beef and pork on the example of Ukraine, it is possible to say that they are declining from year to year. This negatively affects the development of the industry, which loses the opportunity to develop, create new jobs, enter the international market. The problems of meat production that need to be solved $[3,4]$ are faced in:

- European countries [5-7];

- America [8];

- Canada [9].

In researches $[10,11]$ features of functioning and tendencies of development of the market of meat and meat products are considered, the research of a condition of development of meat processing branch is stated and negative tendencies in development of animal husbandry are revealed. In the works [12-14] the institutional bases of formation of the market of meat and meat products are considered, methodical approaches to an estimation of the market of meat are formulated and the model of perspective development of the meat market is developed.

Dynamic changes in the meat processing industry require constant monitoring of unresolved issues, taking into account political, financial, innovative and other aspects that are insufficiently covered in scientific works. Therefore, it is important to study the dynamics and peculiarities of the meat industry, which will help to outline the prospects for the successful realization of potential opportunities and expansion of production.

Thus, the object of research was selected meat processing enterprises on the example of Ukraine. The aim of research is to study aspects of the current state and features of the meat processing industry of Ukraine on the basis of analytical research. 


\section{Methods of research}

The research is substantiated by the use of general scientific and special methods and techniques:

- monographic, statistical groupings, correlation-regression analysis and graphical methods - for a comprehensive study of the current state of meat production; - grouping - to determine the influence of various factors on the level of efficiency of meat production of different types;

- comparison - to conduct a comparative analysis of meat production in different time periods.

\section{Research results and discussion}

In the general structure of agricultural production, livestock products during 2015-2019 ranged from 24.1 to $20.9 \%$ of the total [15]. The largest percentage in this structure was occupied by breeding farm animals. This figure ranged from $11.8 \%$ in 2015 to $10.9 \%$ in 2019 of all livestock products.

The meat and meat products production index for the period from 2015 to 2019 tended to grow slightly (on average $2-4 \%$ annually).

Considering the dynamics of industrial meat production, it is possible to say that the smallest share in this production is beef and veal. Moreover, its production continues to fall (Fig. 1).

During the study period, the highest rate of beef and veal production was observed in 2017 - 76.9 thousand tons, compared to the beginning of 2019, the decline was $12.1 \%$. Also, negative dynamics was observed in pork production - from 247.8 thousand tons in 2015 to 229.4 in 2018 and 238.0 in 2019 . The production of sausages is relatively stable. Thus, from 2015 the positive dynamics was observed until 2018, the growth of production occurred by $7.4 \%$ with a subsequent decrease in 2019 . The largest volumes of production were provided by chicken. During 2015-2016, there was an increase in production by $6.6 \%$ and in subsequent years, production decreased slightly.

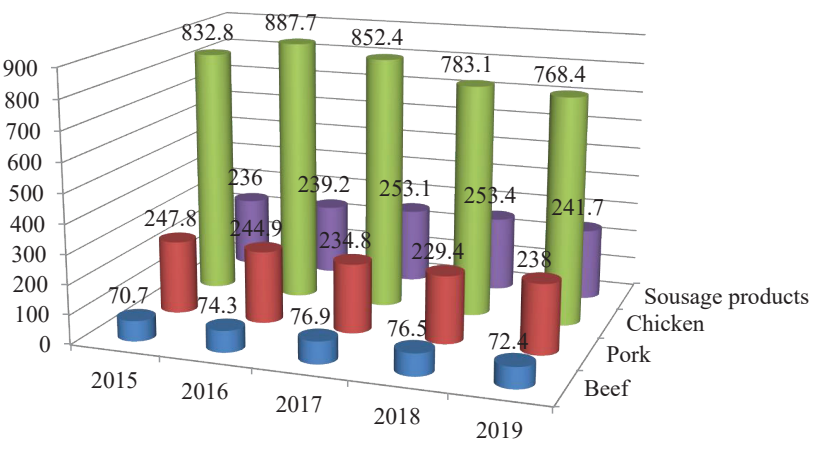

Fig. 1. Industrial production of meat and sausages, thousand tons

The Ukrainian market of meat and meat products is closely connected with the development of raw materials for the industry. The total number of farm animals during the study period decreased significantly (Table 1). Thus, the number of cattle decreased from 3750 thousand heads to 3092, i. e. by $17.6 \%$; pig population - from 7079 thousand heads to 5727 or $19.1 \%$. Only the poultry population increased slightly from 204.0 million in 2015 to 220.0 million in 2019 , or $7.8 \%$.

If to consider the number of farm animals by categories of farms, it can be seen that this number decreases from year to year during the study period, except for poultry (Table 2).

Table 1

Number of farm animals in 1915-2019 (at the end of the year; thousand heads)

\begin{tabular}{|c|c|c|c|c|c|}
\hline Year & Cattle & Pigs & $\begin{array}{c}\text { Sheep } \\
\text { and goats }\end{array}$ & Horses & $\begin{array}{c}\text { Bird, million } \\
\text { heads }\end{array}$ \\
\hline 2015 & 3750 & 7079 & 1325 & 306 & 204.0 \\
\hline 2016 & 3682 & 6669 & 1315 & 292 & 201.7 \\
\hline \% of changes to the previous year & -1.8 & -5.8 & -0.8 & -4.6 & -1.1 \\
\hline 2017 & 3531 & 6110 & 1309 & 265 & 204.8 \\
\hline \% of changes to the previous year & -4.1 & -13.7 & -0.5 & -9.2 & 1.5 \\
\hline 2018 & 3333 & 6025 & 1269 & 244 & 211.7 \\
\hline \% of changes to the previous year & -5.6 & -1.4 & -3.6 & -7.9 & 3.4 \\
\hline 2019 & 3092 & 5727 & 1205 & 224 & 220.0 \\
\hline \% of changes to the previous year & -7.2 & -4.9 & -5.1 & -8.2 & 3.9 \\
\hline \% of changes in 2015-2019 & -17.6 & -19.1 & -9.1 & -26.8 & 7.8 \\
\hline
\end{tabular}

Number of farm animals by categories of farms (at the end of the year; thousand heads)

Table 2

\begin{tabular}{|c|c|c|c|c|c|c|c|c|c|c|}
\hline Farm animals & 2015 & 2016 & $\begin{array}{c}\% \text { to the } \\
\text { previous year }\end{array}$ & 2017 & $\begin{array}{c}\% \text { to the } \\
\text { previous year }\end{array}$ & 2018 & $\begin{array}{c}\% \text { to the } \\
\text { previous year }\end{array}$ & 2019 & $\begin{array}{l}\% \text { to the pre- } \\
\text { vious year }\end{array}$ & $\%$ 2015/2019 \\
\hline \multicolumn{11}{|c|}{ Farms of all categories } \\
\hline Cattle & 3750 & 3682 & 98.2 & 3531 & 95.9 & 3333 & 94.4 & 3092 & 92.8 & 82.4 \\
\hline Pigs & 7079 & 6669 & 94.2 & 6110 & 91.6 & 6025 & 98.6 & 5727 & 95.1 & 80.9 \\
\hline Sheep and goats & 1325 & 1315 & 99.2 & 1309 & 99.5 & 1269 & 96.9 & 1205 & 94.9 & 90.9 \\
\hline Bird, million heads & 204.0 & 201.7 & 98.9 & 204.8 & 101.5 & 211.7 & 103.4 & 220.5 & 104.1 & 108.1 \\
\hline \multicolumn{11}{|c|}{ Enterprises } \\
\hline Cattle & 1270 & 1214 & 95.6 & 1167 & 96.1 & 1138 & 97.5 & 1050 & 92.3 & 82.6 \\
\hline Pigs & 3704 & 3566 & 96.3 & 3304 & 92.6 & 3395 & 102.7 & 3300 & 97.2 & 89.1 \\
\hline Sheep and goats & 187 & 187 & - & 187 & - & 182 & 97.3 & 169 & 92.8 & 90.4 \\
\hline Bird, million heads & 112.0 & 109.8 & 98.0 & 112.5 & 102.5 & 118.8 & 105.6 & 127.8 & 107.6 & 114.1 \\
\hline \multicolumn{11}{|c|}{ Households } \\
\hline Cattle & 2480 & 2468 & 99.5 & 2364 & 95.8 & 2195 & 92.8 & 2042 & 93.0 & 82.3 \\
\hline Pigs & 3375 & 3103 & 91.9 & 2806 & 90.4 & 2630 & 93.7 & 2427 & 92.3 & 71.9 \\
\hline Sheep and goats & 1138 & 1128 & 99.1 & 1122 & 99.5 & 1087 & 96.9 & 1036 & 95.3 & 91.0 \\
\hline Bird, million heads & 92.0 & 91.9 & 99.9 & 92.3 & 92.4 & 92.9 & 100.6 & 92.7 & 99.8 & 100.8 \\
\hline
\end{tabular}


Meat production in general by farms of all categories has a positive dynamics, but this increase is due to an increase in poultry production, which compensates for the decline in meat production of other species. A large share in the production of meat by Ukrainian enterprises also belongs to poultry meat. However, meat production by households during 2015-2019 decreased in all types. Accordingly, the share of meat production by households decreased to a total of $37.0 \%$ in 2015 to $31.9 \%$ in 2019 (Table 3).

Meat production by categories of farms, thousand tons

Table 3

\begin{tabular}{|l|c|c|c|c|c|c|}
\hline \multicolumn{1}{|c|}{ Farm animals } & 2015 & 2016 & 2017 & 2018 & 2019 & $\begin{array}{c}\text { \% of changes } \\
\text { in 2015/2019 }\end{array}$ \\
\hline \multicolumn{7}{|c|}{ Farms of all categories } \\
\hline meat (in slaughter mass) & 2323 & 2324 & 2318 & 2355 & 2492 & 7.3 \\
\hline \multicolumn{7}{|c|}{ including } \\
\hline - beef and veal & 384 & 376 & 363 & 359 & 370 & -3.7 \\
\hline - pork & 760 & 748 & 736 & 703 & 708 & -6.8 \\
\hline - poultry meat & 1144 & 1167 & 1185 & 1259 & 1382 & 20.8 \\
\hline \multicolumn{7}{|c|}{ Enterprises } \\
\hline meat (in slaughter mass) & 1464 & 1490 & 1483 & 1534 & 1698 & 16.0 \\
\hline \multicolumn{7}{|c|}{ including } \\
\hline - beef and veal & 94 & 99 & 95 & 88 & 102 & 8.5 \\
\hline - pork & 400 & 397 & 373 & 360 & 385 & -3.75 \\
\hline - poultry meat & 968 & 993 & 1014 & 1085 & 1210 & 25.0 \\
\hline \multicolumn{7}{|c|}{ Households } \\
\hline meat (in slaughter mass) & 859 & 834 & 835 & 821 & 794 & -7.6 \\
\hline \multicolumn{7}{|c|}{ including } \\
\hline - beef and veal & 290 & 277 & 268 & 271 & 268 & -7.6 \\
\hline - pork & 360 & 351 & 363 & 343 & 323 & -10.3 \\
\hline - poultry meat & 176 & 174 & 171 & 174 & 172 & -2.3 \\
\hline
\end{tabular}

Analyzing meat production per capita, it is possible to say that this figure increased slightly during the study period, namely from $54 \mathrm{~kg}$ of meat (in slaughter weight) to $59 \mathrm{~kg}$.

Considering the production of meat by region, it is possible to say that the largest share of this production (1524 thousand tons in slaughter weight), namely $61.2 \%$ provide six areas, namely:

- Vinnytsia (459);

- Volyn (115);

- Dnipropetrovsk (254);

- Kyiv (217);

- Lviv (130);

- Cherkasy (349).

A record number of farm animals was received by processing enterprises in 2019 - 1891.5 thousand tons (Table 4).

Production of sausages and meat products is concentrated mainly in 5 regions - Dnepropetrovsk, Donetsk, Kirovograd, Poltava and Kharkiv, which account for $72.8 \%$ of total production, or 172.2 thousand tons out of 236.6 in Ukraine as a whole.

The wholesale turnover of meat and meat wholesalers has been growing every year. Thus, in 2016 it amounted to 495,639 dollars USA, which is 12.7 more than the previous year. In 2017 and 2018, this figure increased to 679,692 and 1,219,911 dollars USA, and its growth was $36.7 \%$ in 2017 and a record $80 \%$ in 2018. In general, the wholesale turnover of wholesale trade enterprises by product group «meat and meat products» during the study period increased from 439,672 to $1,219,911$ dollars USA, or a total of $177.5 \%$.

Table 4

Receipt of livestock products at processing enterprises (thousand tons)

\begin{tabular}{|l|c|c|c|c|c|}
\hline \multicolumn{1}{|c|}{ Indicator } & 2015 & 2016 & 2017 & 2018 & 2019 \\
\hline \multicolumn{7}{|c|}{ Farm animals (live weight) } \\
\hline received - all & 1689.9 & 1621.0 & 1717.6 & 1752.3 & 1891.5 \\
\hline \multicolumn{6}{|c|}{ including purchased from } \\
\hline - enterprises & 376.5 & 331.4 & 316.6 & 302.7 & 300.0 \\
\hline - households & 18.7 & 22.3 & 25.2 & 24.8 & 21.3 \\
\hline \multicolumn{7}{|c|}{ From the total income by species of farm animals } \\
\hline - cattle & 123.8 & 141.2 & 129.2 & 124.4 & 120.6 \\
\hline - pork & 325.3 & 342.9 & 329.4 & 308.5 & 317.3 \\
\hline - chicken & 1203.3 & 1136.1 & 1257.4 & 1317.8 & 1451.7 \\
\hline
\end{tabular}

Raw material production and processing are closely interrelated. Today, it is extremely important to reconcile the interests of producers and processors so that the market is predictable, has a defined development strategy, focused on both increasing domestic consumption and realizing the export potential of the meat industry. The high price of meat, due to the high cost of its production, has effectively cut off Ukraine's path to foreign markets. For example, Ukrainian pork is not competitive there due to its high cost.

The highest price is only in China. For many years, Ukraine has been among the world's 10 largest importers of pork. Ukraine is again increasing the volume of imports of pork, as the domestic market has artificially created a shortage of pigs, which provokes a constant rise in prices for them. On the other hand, even with a $48 \%$ rise in the price of pig carcasses in the European Union over the past year, pork produced there remains cheaper than that of pigs raised in Ukraine.

For the successful development of the industry it is necessary to take a number of measures both at the level of the state as a whole and at the level of each enterprise in particular. Yes, the state has:

- protect and encourage domestic producers to increase production;

- present the products of domestic producers at international specialized exhibitions, seminars to expand markets outside the country;

- harmonize domestic standards of safety and quality of products in accordance with international standards; - intensify the system of control over the quality and safety of meat products;

- at the level of meat processing enterprises it is necessary to implement the standards of the ISO 9001, ISO 14001, ISO 22000, HACCP, OHSAS 18001, PAS 223 series;

- use resource-saving technologies;

- update the material and technical base and carry out technical re-equipment of the main equipment for the production of meat products, which meets European requirements for quality and safety;

- load production capacity with domestic raw materials. Only under such conditions will it be possible to integrate the Ukrainian meat industry into the global market, to create conditions for it to be competitive in the world, and for domestic producers to increase production volumes. 


\section{Conclusions}

The study showed that the production of livestock products in general and meat in particular is one of the leading sectors of agriculture, which is involved in providing the population with wholesome food and solving the food problem. It has been found that in recent years there have been some trends in the dynamics and structure of meat production and consumption towards cheaper poultry meat. It is explained that the main reason for this situation is the reduction of production; significant increase in retail prices for all types of products; low incomes of the majority of the population, its social differentiation. The study revealed a negative trend in the meat processing industry, which is that Ukraine sells more livestock and poultry than raised, resulting in a reduction in livestock, the market constantly receives products and demand is met (within the solvency of the population), but the resources of meat products are not reproduced.

The research results show that for the successful development of the industry it is necessary to take a number of measures both at the level of the state as a whole and at the level of each enterprise in particular. The state must protect and stimulate domestic producers; to harmonize domestic standards of safety and quality of products in accordance with international standards; to intensify the system of control over the quality and safety of meat products. The research results will be useful for meat processing enterprises, which need:

- actively implement quality and safety standards;

- use resource-saving technologies;

- update the material and technical base and carry out technical re-equipment of the main equipment for the production of meat products that meets European requirements for quality and safety;

- load production capacities with domestic raw materials.

Today, a promising task is to integrate the Ukrainian meat industry into the global market, creating conditions for increasing its competitiveness in the world, increasing production by domestic producers.

\section{References}

1. Yavuz, F., Bilgic, A., Terin, M., Guler, I. O. (2013). Policy implications of trends in Turkey's meat sector with respect to 2023 vision. Meat Science, 95 (4), 798-804. doi: http:// doi.org/10.1016/j.meatsci.2013.03.024

2. Wyness, L. (2016). The role of red meat in the diet: nutrition and health benefits. The Proceedings of the Nutrition Society, 75 (3), 227-232. doi: http://doi.org/10.1017/s0029665115004267

3. Uçum, İ., Gülçubuk, B. (2018). Hayvancılığa Dayalı Yerel Sanayi İșletmelerinde Üretim ve Yerel Ekonomiye Katk1 Sürecinde Yaşanan Sorunlar. Kahramanmaraş Sütçü Imam Üniversitesi Tarm Ve Doğa Dergisi, 21, 44-54. doi: http://doi.org/10.18016/ ksutarimdoga.v21i41625.472849
4. Demirkol, C., Azabağaoğlu, M. O. (2017). Analysis of business structures on capacity usage in determining encountered problems of red meat industry in Turkey. Social Sciences Research Journal, 6 (4), 359-369.

5. Ağır, H. B., Akbay, C. (2018). Factors affecting on the producers' utilization of beef cattle support. KSU Journal of Natural Sciences, 21 (5), 738-744. doi: http://doi.org/10.18016/ ksudobil.407625

6. Saygın, Ö., Demirbaş, N. (2017). The current situation of red meat sector in Turkey and solution recommendations. Animal Production, 58 (1), 74-80. doi: http://doi.org/10.29185/hayuretim.335515

7. Verbeke, W., Van Wezemael, L., Barcellos, M. D., Kugler, J. O., Hocquette, J. F., Ueland, O., Grunert, K. G. (2010). European beef consumers' interest in a beef eating-quality guarantee: insights from a qualitative study in four EU countries. Appetite, 54 (2), 289-296. doi: http://doi.org/10.1016/j.appet.2009.11.013

8. Saitone, T. L.; Martin, P. L., Goodhue, R. E., Wright, B. D. (Eds.) (2018). Livestock and rangeland in California. California agriculture dimensions and issues (Chap. 9, Giannini Foundation Information Series). Berkeley: Giannini Foundation of Agricultural Economics.

9. Aalhus, J. L., López-Campos, Ó., Prieto, N., Rodas-González, A., Dugan, M. E. R., Uttaro, B., Juárez, M. (2014). Review: Canadian beef grading - Opportunities to identify carcass and meat quality traits valued by consumers. Canadian Journal of Animal Science, 94 (4), 545-556. doi: http://doi.org/10.4141/cjas-2014-038

10. D. Er, S., Özçelik, A. (2016). The examination of economic structure of cattle fattening farms in Ankara province by factor analysis. Yuzuncu Yll University Journal of Agricultural Sciences, 26 (1), 17-25. doi: http://doi.org/10.29133/yyutbd.236283

11. Markina, I. A., Bolshakova, Ye. L. (2019). Osoblyvosti funktsionuvannia ta tendentsii rozvytku rynku miasa ta miasnoi produktsii v Ukraini. Ukrainskyi zhurnal prykladnoi ekonomiky, 4 (4), 119-128.

12. Berher, A. D. (2017). Current trends in Ukraine meat industry. Intelekt XXI, 1, 41-51.

13. Leskiv, I. Yu. (2018). Instytutsionalni osnovy formuvannia rynku miasa ta miasnoi produktsii. Economy and Society: a Modern Vectors of Development. Part I. Leipzig: Baltija Publishing, 57-59.

14. Leskiv, I. Yu. (2018). Metodychni pidkhody do otsinky rynku miasa. Eurasian academic research journal, 2 (20), 102-109.

15. Verner, I. Ye. (Ed.) (2020). Statystychnyi shchorichnyk Ukrainy za 2019 rik Derzhavna sluzhba statystyky Ukrainy. Kyiv, 465. Available at: http://ukrstat.gov.ua/druk/publicat/kat_u/publ1_u.htm

Iryna Vlasenko, Doctor of Medical Sciences, Professor, Head of Department of Commodity Science, Expertise and Commercial Business, Vinnytsia Institute of Trade and Economics of Kyiv National University of Trade and Economics, Vinnytsia, Ukraine, ORCID: https:// orcid.org/0000-0001-9995-2025,e-mail:vlasenkoivol@gmail.com

Tetiana Semko, PhD, Associate Professor, Department of Tourism, Hotel and Restaurant Business, Vinnytsia Institute of Trade and Economics of Kyiv National University of Trade and Economics, Vinnytsia, Ukraine, ORCID: https://orcid.org/0000-0002-1951-5384, e-mail:semko1965@ukr.net

Olga Ivanisheva, Senior Lecturer, Department of Tourism, Hotel and Restaurant Business, Vinnytsia Institute of Trade and Economics of Kyiv National University of Trade and Economics, Vinnytsia, Ukraine, ORCID: https://orcid.org/0000-0002-6012-0974, e-mail: olya.ivanisheva@gmail.com 